\title{
Лікування пацієнтів із симптоматичними тунельованими коронарними артеріями
}

\author{
Гогаєва О. К. \\ ДУ «Національний інститут серцево-судинної хірургії імені М. М. Амосова НАМН України», м. Київ, Україна
}

Резюме. Стаття присвячена аномалії розташування вінцевих артерій - тунельованим коронарним артеріям. На основі найбільшого у світі досвіду, який налічує 347 симптоматичних пацієнтів, автор впровадив у практику ефективні персоналізовані методи лікування цієї аномалії.

Ключові слова: тунельовані коронарні артерії, м’язові «місточки», інтрамуральний хід, лікування.

Тунельована коронарна артерія (ТKA) - вроджена аномалія розташування вінцевої артерії під м'язовим сегментом. Суть цієї особливості розташування вінцевої артерії полягає в наявності систолічної компресії тунельованого сегмента артерії, що само по собі викликає сумнів у ії клінічній значущості. Можливо, саме тому ставлення до ТКА в медичному колі неоднозначне і часто зневажливе, з огляду на сприятливий перебіг цієї аномалії в більшості випадків. Проте наявні описання розвитку інфарктів міокарда, раптової серцевої смерті $[1,2]$ при фізичних або емоційних навантаженнях як у молодому, так і в похилому віці [3-5]. Вивчення механізмів виникнення ішемії міокарда при систолічній компресії залишається актуальним не тільки з наукової точки зору, а й для обгрунтування патогенетичного підходу до лікування ТКА.

Мета роботи - обгрунтувати лікування симптоматичних пацієнтів з ТКА з урахуванням причин виникнення ішемії міокарда, оцінити ефективність лікування та розробити алгоритм ведення пацієнтів з ТКА.

Матеріали і методи дослідження. Протягом 13 років в Інституті спостерігалося 347 пацієнтів із симптоматичними ТКА. Усім пацієнтам проводили ЕКГ, ЕхоКГ та коронаровентрикулографію.

Результати. Адекватне лікування пацієнтів з ТКА неможливе без розуміння механізму виникнення ішемії міокарда під час систолічної компресії вінцевої артерії [6]. Непорозуміння стосовно ішемії міокарда виникають через недооцінювання лікарями клінічної значущості цієї аномалії. Однією з причин виникнення ішемії міокарда при ТКА є діастолічна дисфункція, яка призводить до пролонгації систолічної компресії на першу фазу діастоли. Аналіз клінічних даних показав ключову роль діастолічної дисфункції на основі виникнення симптомів у пацієнтів віком 30-40 років у поєднанні 3 гіпертрофією лівого шлуночка $(80,9 \%)$ та визначення трансмітрального потоку при доплер-ехокардіографії. У більшості пацієнтів $(84,1 \%)$ спостерігалася діастолічна дисфункція за псевдонормальним типом (E/A>1).
Запропоновано такі методи лікування ТКА: медикаментозна терапія, стентування тунельованого сегмента вінцевої артерії, хірургічна корекція. Метод лікування пацієнта визначався індивідуально, з урахуванням довжини тунельованого сегмента, ступеня систолічної компресії, наявності супутнього кардіологічного захворювання.

Медикаментозна терапія, що включає антиагреганти, бета-блокатори, антагоністи кальцію, анксіолітики, препарати магнію і статини, була призначена 296 (85,3\%) пацієнтам. У 285 (96,3\%) випадках спостерігалося значне покращення самопочуття, в $11(3,7 \%)$ пацієнтів, резистентних до медикаментозної терапії протягом 3-6 місяців, була виконана реваскуляризація міокарда (стентування або АКШ). У пацієнтів, які знаходяться на індивідуально підібраній медикаментозній терапії, крім поліпшення самопочуття, в деяких випадках спостерігалось зменшення ступеня систолічної компресії при виконанні повторної коронарографії через $2-3$ роки від початку лікування.

Пряме ендопротезування тунельованого сегмента вінцевої артерії з використанням drug eluting-стентів було виконано 26 пацієнтам $(7,5 \%)$ з важкими нападами стенокардії. На рисунку 1 представлено результат стентування тунельованого сегмента ПМШГ ЛКА через 2 роки після ендоваскулярного втручання.

Широке використання цього методу лікування стримують літературні дані про високий відсоток рестенозів, натомість в Інституті рестенози в стентах при ТКА виникли у $5(19,2 \%)$ пацієнтів. Однак, незважаючи на безпеку та ефективність цього методу, показанням для такого міні-інвазивного лікування мають бути лише недовгі (до 15 мм) тунельовані сегменти і наявність резистентності до медикаментозної терапії.

Хірургічна корекція виконувалась при неефективності медикаментозної терапії, неможливості стентування або за наявності супутньої кардіальної патології. Операції виконали 41 (11,8\%) пацієнту, у тому числі: 17 - АКШ; 12 - резекції аневризм лівого шлуночка 3 реваскуляризацією міокарда; 1 - супракоронарна міо- 
1
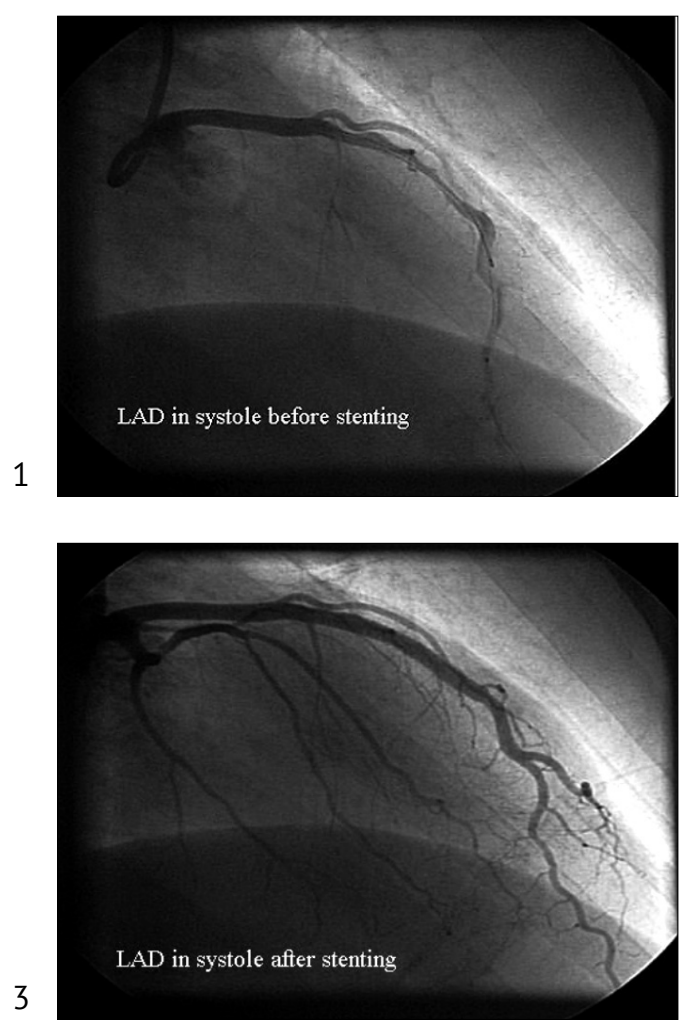
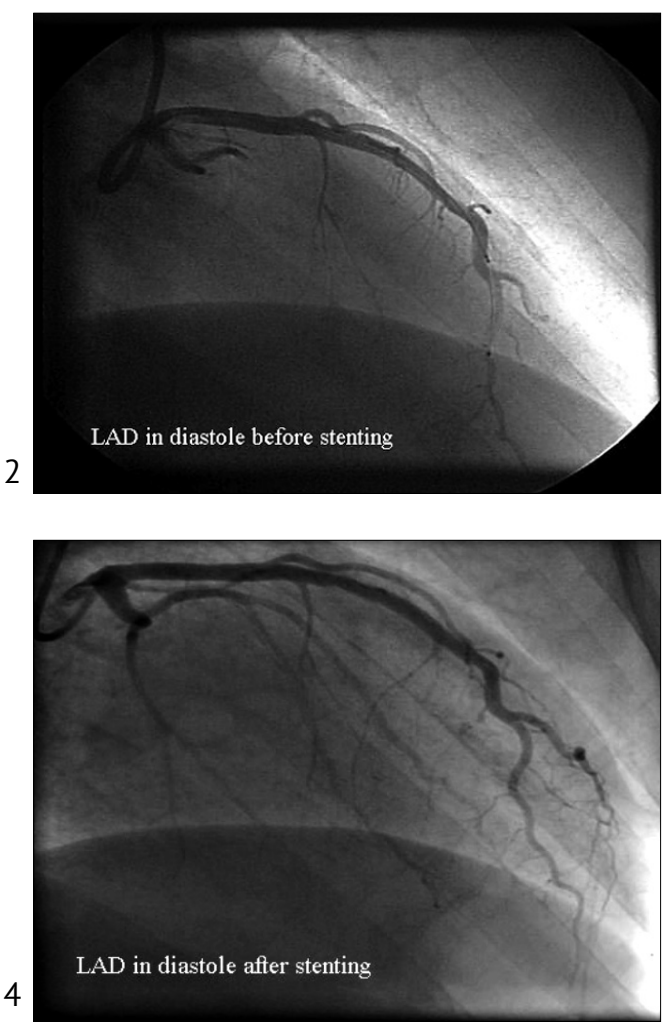

Рисунок 1. Результати стентування тунельованого сегмента ПМШГ ЛКА, ангіографія пацієнта А., 42 р.: 1 - ПМШГЛКА в систолу; 2 - ПМШГЛКА в діастолу; 3 - ПМШГЛКА в систолу через 2 роки після стентування; 4 - ПМШГЛКА в діастолу через 2 роки після стентування

томія; 9 - епікардіотомія з денервацією вінцевої артерії; двом пацієнтам із гіпертрофічною кардіоміопатією (ГКМП), резистентним до медикаментозного лікування, виконана операція Morrow.

1

Результати ангіографії хворої М., 58 р., з обструктивною формою ГКМП у поєднанні з інтраміокарді-

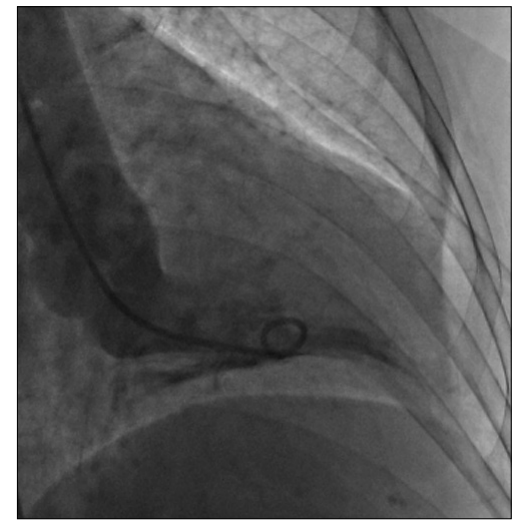

альним розташуванням ПМШГ ЛКА наведено на рисунку 2.

Враховуючи те, що систолічна компресія ПМШГ ЛКА була лише $30 \%$, було прийнято рішення відмовитися від шунтування, а виконати класичну операцію Morrow. Проте в післяопераційний період виникли
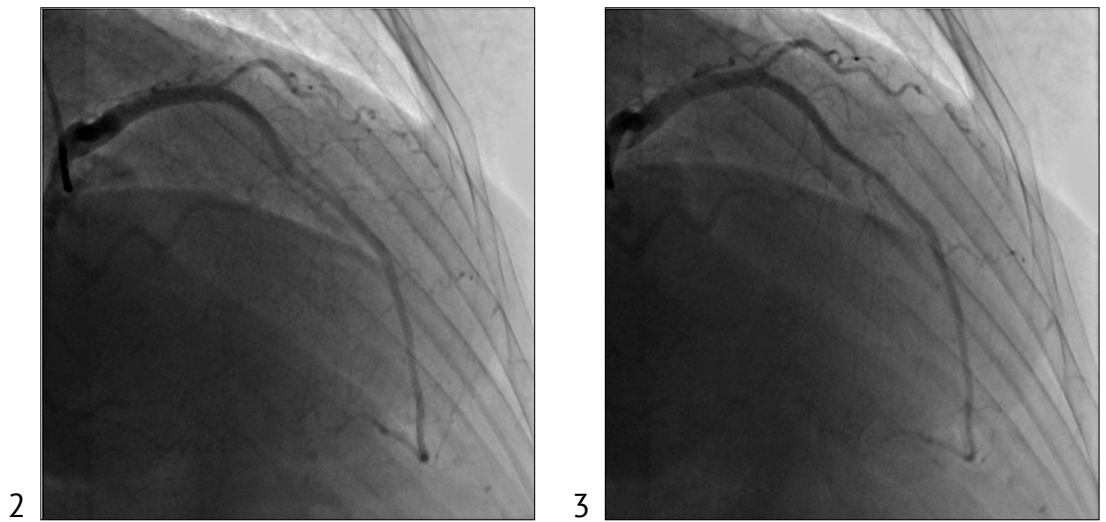

Рисунок 2. Ангіографія пацієнтки М., 58 р.: 1 - ліва вентрикулографія; 2 - ПМШГЛКА в систолу із систолічною компресією 30\%; 3 - ПМШГу діастолу 

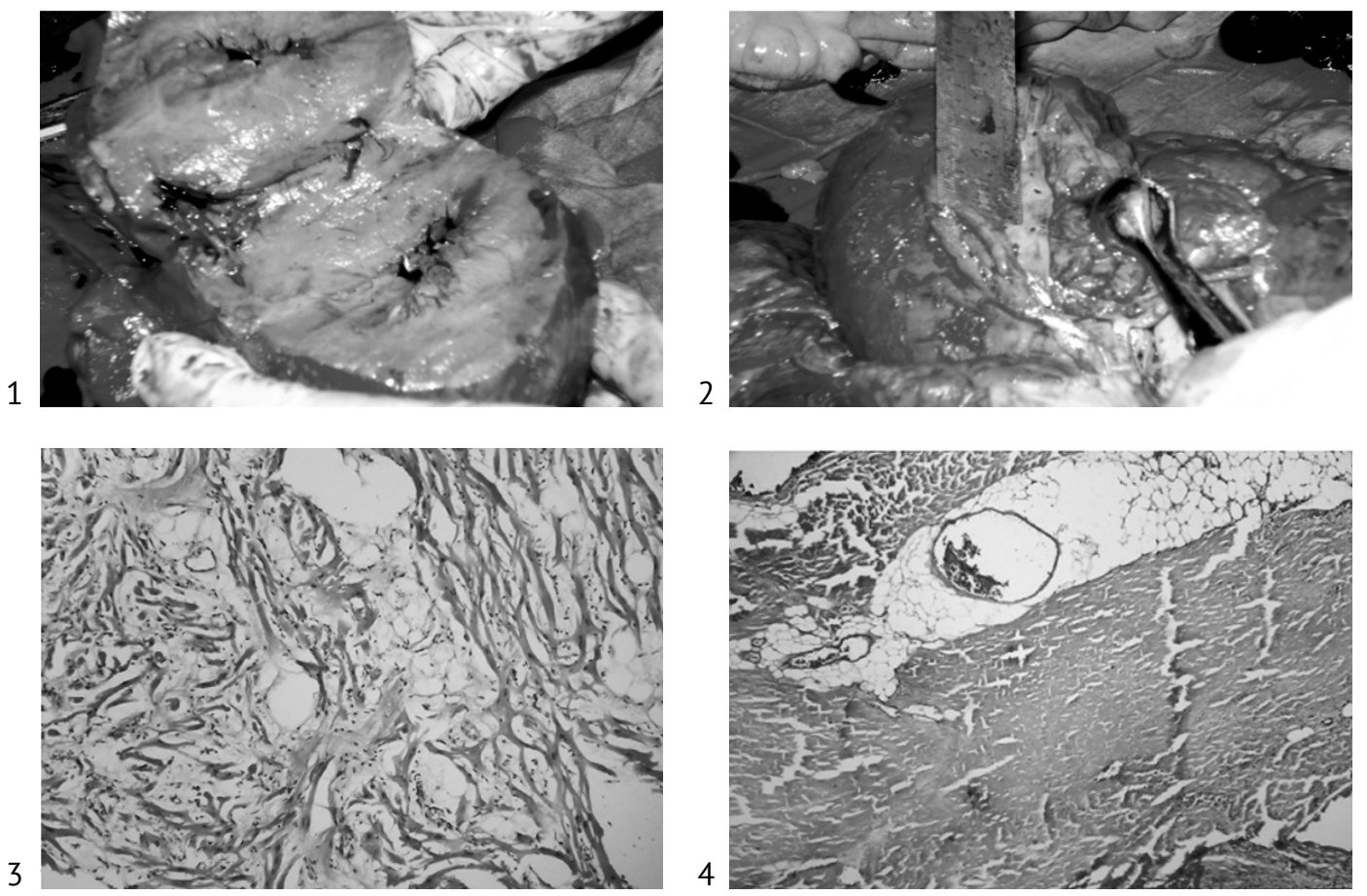

Рисунок 3. Аутопсія пацієнтки М: 1 - виражена гіпертрофія стінок лівого шлуночка з товщиною стінки 30 мм; 2 - пірнаюча середня третина ПМШГЛКА, довжина 32 мм, глибина 4 мм;

3 - мікроскопія міокарда-disarray; 4 - міжшлуночкова перегородка з ТКА (ПМШГЛКА) та ознаками інфаркту міокарда

1
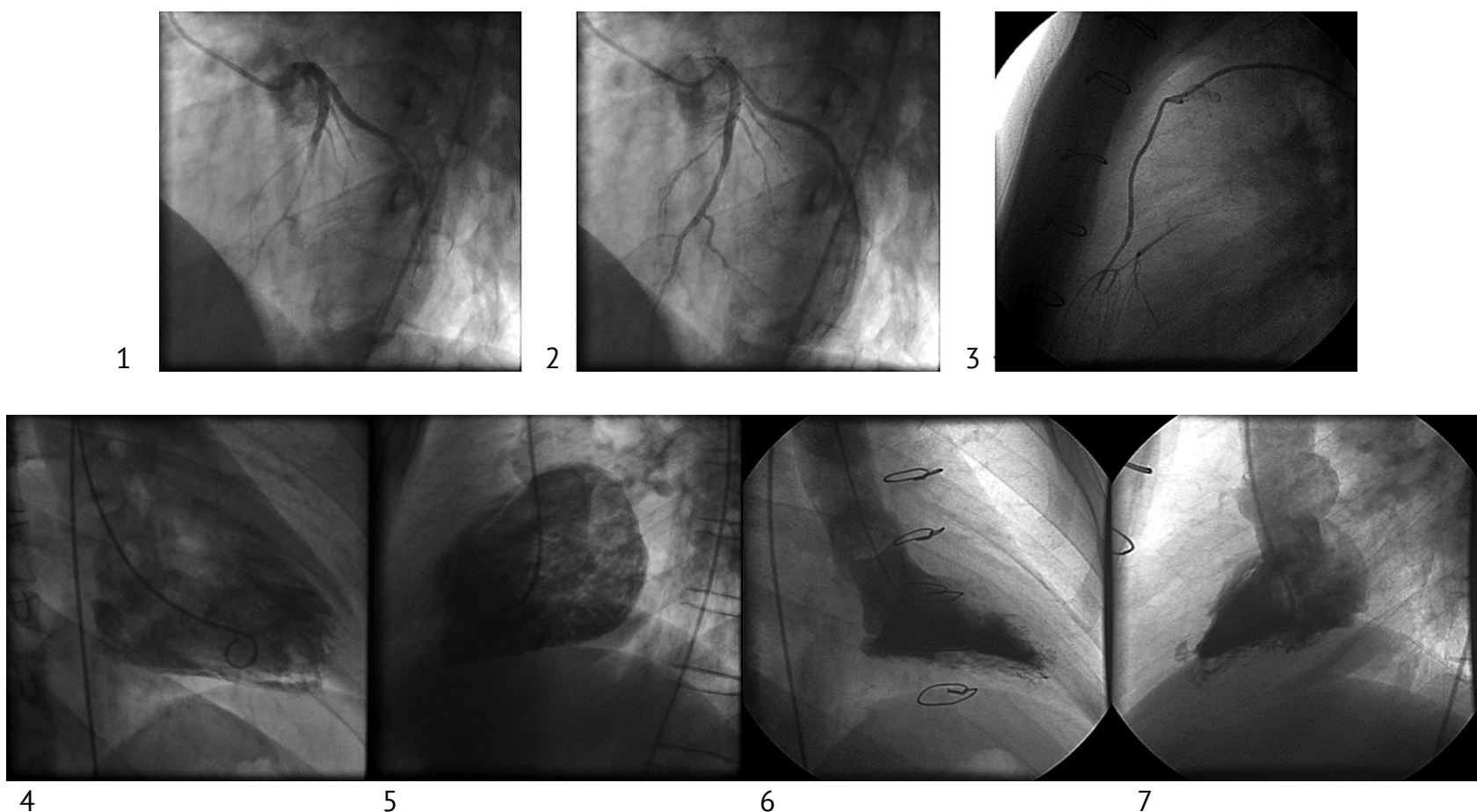

Рисунок 4. Ангіографічні дані хворого Д., 40 р., із тромбованою аневризмою лівого шлуночка: 1 - ПМШГ ЛКА в систолу з вираженою систолічною компресією; 2 - ПМШГЛКА в діастолу; 3 - венозний шунт у ПМШГЛКА в систолу через 3 місяці після операції; 4, 5 - вентрикулографія перед операцією у двох проекціях; 6, 7 - вентрикулографія у двох проекціях через 


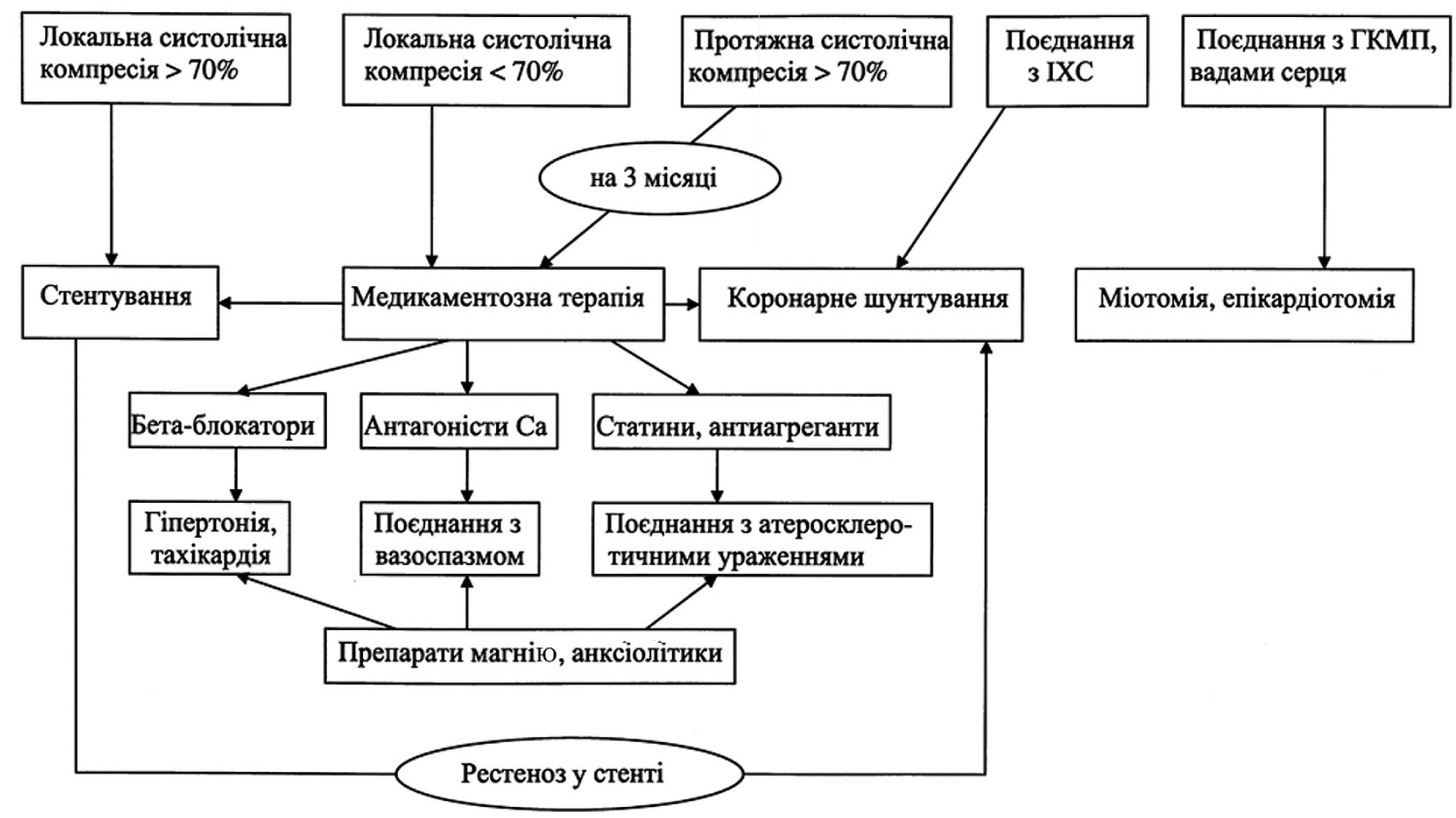

Рисунок 5. Алгоритм лікування пацієнтів із симптоматичними TKA

важкі порушення ритму серця, гостра серцева недостатність, що призвело до смерті пацієнтки. Під час аутопсії виявлено інфаркт міокарда в зоні міжшлуночкової перегородки, ПМШГ ЛКА занурювалася в серцевий м'яз на глибину 4 мм упродовж 32 мм. На рисунку 3 представлено дані аутопсії пацієнтки М.

Наведений приклад показує значення цієї аномалії розташування вінцевої артерії як додаткового фактору розвитку життєзагрозливих серцевих аритмій і динамічності систолічної компресії тунельованого сегмента вінцевої артерії.

Також спостерігалися пацієнти з ускладненими формами IXC. У 12 пацієнтів із післяінфарктною аневризмою лівого шлуночка було виконано АКШ з резекцією аневризми лівого шлуночка. Ангіографічний результат однієї такої операції через 3 місяці після втручання представлено на рисунку 4.

Віддалений результат різних методів лікування пацієнтів із симптоматичними ТКА за період від 12 місяців до 13 років був сприятливий. Усі пацієнти відчувають значне покращення самопочуття.

Найбільший світовий досвід лікування пацієнтів із симптоматичними ТКА з добрими віддаленими результатами дозволив розробити алгоритм лікування пацієнтів із цією аномалією (рисунок 5).

\section{Висновки}

1. Виникненню ішемії міокарда при ТКА сприяє пролонгація систолічної компресії на першу фазу діастоли.

2. Велика протяжність тунельованого сегмента вінцевої артерії є протипоказанням до стентування у зв'язку з високим ризиком рестенозів.

3. На тлі ТКА навіть із мінімальною систолічною компресією можливе виникнення гострого коронарного синдрому, інфаркту міокарда, шлуночкових тахікардій, розвиток ускладнених форм ішемічної хвороби серця.

4. Індивідуальний підхід у лікуванні пацієнтів із цією аномалією допомагає запобігти життєзагрозливим подіям і покращити якість життя хворих при ТКА.

5. За результатами проведеної роботи розроблено та впроваджено в практику алгоритм лікування симптоматичних пацієнтів із ТКА.

\section{Список використаних джерел}

1. Grigoriu C, Astarastoae V, Grigoriu B. Myocardial bridging and sudden death. Rev. Med. Chir. Soc. Med. Nat. Iasi. 2001:105(1);77-82.

2. Nishida N, Hata Y. A Case of Sudden Unexpected Death with the Presence of Multiple Myocardial Bridges. Int $\mathbf{J}$ Clin Cardiol. 2017:4;099. 
3. Lee MS, Chen C-H. Myocardial Bridging: An Upto-Date Review. The Journal of invasive cardiology. 2015;27(11):521-528.

4. Yuan SM. Myocardial bridging. Braz J Cardiovasc Surg. $2016 \mathrm{Feb} ; 31(1): 60-2$.

5. Cerrato E, Barbero U, D'Ascenzo F, et al. What is the optimal treatment for symptomatic patients with isolated coronary myocardial bridge? A systematic review and pooled analysis. J Cardiovasc Med (Hagerstown). 2017 Oct; 18(10):758-770.

6. Гогаева ЕК. Механизм развития ишемии миокарда при миокардиальных мостиках. Серце і судини. 2013:1;8-11.

\section{Treatment for patients with symptomatic tunneled coronary arteries}

\section{Olena Gogayeva}

National M. M. Amosov Institute of Cardiovascular Surgery National Academy of Medical Sciences of Ukraine, Kyiv, Ukraine

The article focuses on the treatment of abnormal coronary artery location, so-called tunnelled coronary artery (TCA).

Objective: to show our experience in treatment of symptomatic patients with TCA taking into account the mechanism of ischemia development. To evaluate efficacy of different treatment methods and to show our algorithm of treatment for patients with TCA.

Material and methods: Over 13 years, we observed 347 patients with symptomatic TCA diagnosed during coronary angiography. The following clinical examinations were performed for all patients: ECG, echocardiography, and coronary angiography

Results: Misunderstandings of myocardial ischemia causes during myocardial bridging (MB) occurs primarily when physicians underestimate the clinical significance of this anomaly. In our opinion, one of the factors causing myocardial ischemia during $\mathrm{MB}$ is diastolic dysfunction, which leads to the prolongation of systolic compression at the first phase of diastole. There are the following methods of treatment of symptomatic patients with TCA: drug therapy, stenting of a tunnelled segment and surgical correction. The method of treatment for patients was determined strictly on an individual basis, taking into account the length of a tunnelled segment of the coronary artery, the degree of systolic compression of the coronary artery and the presence of concomitant cardiac diseases. Despite the safety and efficacy of endovascular treatment, indications for this minimally invasive method should only be performed in cases of patients who are resistant to drug therapy and have an unextended $(<15 \mathrm{~mm})$ tunnelled segment of the coronary artery. Long-term results of different types of treatment were mostly good in patients with symptomatic TCA for a period of 12 months to 13 years. All patients show significant improvement in their health condition. An individual approach in treating patients with this anomaly helps to avoid life-threatening events and to improve quality of life for patients with this anomaly.

Keywords: tunnelled coronary arteries, intramural course of coronary arteries, myocardial «bridging», treatment.

Стаття надійшла в редакцію 12.02 .2019 р. 